\title{
Women's Role in the Development of South Sulawesi's Small and Medium Enterprises Home Industry through Social Media
}

\author{
Jumidah Maming ${ }^{1}$, Abdul Razak Munir ${ }^{2}$, Nuraeni Kadir ${ }^{3}$ and Andi Reni ${ }^{4}$ \\ ${ }^{1}$ Hasanuddin University, Indonesia \\ ${ }^{2}$ Hasanuddin University, Indonesia \\ ${ }^{3}$ Hasanuddin University, Indonesia \\ ${ }^{4}$ Hasanuddin University, Indonesia
}

\begin{abstract}
The social media provided the prospect of further development of Small and Medium Enterprises. Because of that the companies specifically the home industries that utilizes social media in developing its business requires special attention due to its strategic nature. In addition, the low number of women who utilized social media shows low interest towards social media. Another important thing to note is that the women's capability of utilizing the social media needs to be improved as well. To do so, training along with workshops with practical and simple technique may be used to increase their knowledge on social media.
\end{abstract}

Keywords: small to medium sized industries, social media, home industry

\section{Introduction}

The role of women is a set of behaviors expected to follow the social position given to women. The roles dictate the actions and behaviors of women in certain situations in order to fulfill their own expectations and others as well. The social roles of women are as follows:

1. The role of housewife, mother and teacher of her children as well as the manager of the house

2. The role of women in society which concludes all actions outside of the home environment

3. The role of women in professional organizations shows the women as independent along with women's self-actualization (Droge, 1994)

According to statistics, $50.3 \%$ of total population of Indonesia are comprised of women. This shows the higher number of women compared to men. With such high number of women, the potential of women becoming subject of the nation's economic growth and development must be developed. The role of women in economy can be seen through the improvement of family economy through entrepreneurship as well as educated labor.

The development of social media influenced the organization's method of communication. The Web 2.0 provided the people the means to grow business and social relationship as well as information sharing. Marketing through social media usually centers around on the effort to create an internet content that's interesting enough and are able to persuade the viewer to share with their social network. Social media became a platform that is easily accessible by anyone, which became the opportunity for companies to increase the society's knowledge about their product and work as well as facilitate the interactions between customers and the company itself (Vinerean, 2013).

According to the 2017 data retrieved from Badan Pusat Statistik, the total population of Indonesia is 209 million individuals making it the fourth most populated country in the world. From that total population, $50.4 \%$ of them (105 million individuals) are women and 49.76\% (104 million individuals) are men. Half of the total population lives in the cities, in the urban areas $50.1 \%$ of the population are women while the $49.9 \%$ are men, in the rural areas $49.7 \%$ of the population are women while $50.3 \%$ of them are men.

Furthermore, there are fewer women that managed to finish university education compared to men. In urban areas, $27 \%$ of women did not finish elementary school, $28 \%$ finished elementary school, $18 \%$ only finished junior high school, $22 \%$ finished high school and only $7 \%$ finished college/university education. On the other hand only 19\% of men didn't finish elementary school, 
$26 \%$ finished elementary school, $20 \%$ finished junior high school, $28 \%$ finished high school and $7 \%$ finished college/university education.

In rural areas $48 \%$ of the women did not finish elementary school, $34 \%$ of them graduated, $11 \%$ finished junior high school, $6 \%$ finished high school and only 1\% finished college/university education. The men on the other hand only had $38 \%$ of them who didn't finish elementary school, $36 \%$ finished elementary school, 14\% finished junior high school, 10\% finished high school and 1\% finished college/university education.

The degree of education will correlate and positively influence the economic condition as well as the welfare, this is due to the fact of having a low degree of education will decrease the chance of obtaining job employment it also reduces the possibilities of being accepted as member of parliament as well as other positions in the government offices (Sri Lestari, 2007).

Beside the factor of education, the ideologies, society structure and culture also proved to be detrimental towards women's position in the society. The patriarchal ideology had influenced the structure and socio-cultural system of the society which puts women to a disadvantage. Combined with internalization of the patriarchy values which supports the male dominance had helped the creation of the role and status women as to be second to men. This condition reflects the social, political, economic, cultural, law and religious discrimination towards women.

The issue is that there is a certain limitation towards women's chance of receiving better education, access to better economy and organizations still applies. The traditional culture where there is a disparity between genders in all segments of life is the main condition that had led women to a position of disadvantage.

The reality is that the men/husband that were supposed to be the head of household had become partially unemployed or underemployed while the household needs and children education costs stays the same. In order to satisfy the household needs, the wives that were unemployed will have to find a profitable employment or work. In truth, women have the potential to create various kinds of productive works that can help improve the household economy.

Technology and information development had provided prospects of improvement towards Indonesia's financial crisis. Other industries are plagued with labor strike, illegal money charging or fraud as well as physical harassments. Due to such events, businesses that utilizes information technology will require special attentions due to its strategic nature towards Indonesian society. Indonesian entrepreneurs are mostly comprised of men with few women, the problem that exist is that the women entrepreneurs lack knowledge on how to utilize technology when information technology in this era of globalization had become a main element in the society. There have been numerous examples of how technology became integrated in business practices, one of such is the transaction process of selling, purchasing and ordering that are now become more efficient due to technology support. There are several factors that caused the male dominance in technology with one of them due to low women interest towards technology itself.

The situation that has been described above give reason to the need to research about women's role in business development through information technology as a mean to support economic recovery in Indonesia.

There are a number of questions that this research aims to answer, such questions are:

1. What is women's role in the development of Small and Medium Enterprises (SME's) through social media on South Sulawesi's home industries?

2. Does women's role affect the development of Small and Medium Enterprises (SME's) through social media on South Sulawesi's home industries?

3. How big are the effects of women's role with social media skills on the development of Small and Medium Enterprises (SME's) on South Sulawesi's home industries?

The research itself aims to:

1. Analyze the role of women in the development of Small and Medium Enterprises (SME's) on South Sulawesi's home industries 
2. Analyze whether or not women's role affects the development of Small and Medium Enterprises (SME's) on South Sulawesi's home industries

3. Analyze how big are the effects of women's role with social media skills in the development of Small and Medium Enterprises (SME's) on South Sulawesi's home industries

Generally, there are a few of us that realizes that women are facing gender specific issues, not only amongst men but also women themselves does not realize of such issue this led to few research on such matters. The reason behind such situation is due to the fact that certain values had been enforced that dictates the men as well as women's role in the society, in which the women only has the right to become a mother and household keeper. This led to a public opinion about women's activities outside household management to be uncommon if not weird and rejected, and thus emerged the paradigm that states that women do not require higher education due to their sole purpose is to become household keeper (Sri Lestari, 2007).

As societies advance through the era of globalization, women had begun to show their capabilities even though still inadequate in comparison to men's capabilities. BPS data on the year 2000 shows that, there had been an increase of women's motivation to participate in entrepreneurship or other productive means with the reason of reducing unemployment, as well as creating job employments. In truth there had been a number of Indonesian women that participated in entrepreneurship but due to gender specific issues, efforts towards women empowerment or training and skills development had become limited if not halted.

According to Cakrawala Cinta (Ide Usaha Kecil dan Madya, 1994), there is a difference gap that affects both men and women entrepreneurship, in which most women find it difficult to progress due to reasons of:

1. Women had not been taught to compete; their competitive spirit had not been developed since childhood. They tend to avoid confrontation and at times lack teamwork efforts.

2. Women tends to fail to see the broader picture of an organization, their tendency to focus on small details and overlook the general performance of an organization may halt or disturb their leadership skills development

3. Women tend to become emotional most of the time even in such situations that require professionalism, such situation may be when facing criticism of their work or looks

4. Women tend to be discouraged when it comes to taking risks, this limits their actions to be mediocre or average

5. Women lacks the aggressive behavior due to general opinion that states that women should not be aggressive thus discouraging them from expressing their ideas and opinion assertively and rejecting the wrong actions that are conducted by their fellow workers

6. Women prefer to react rather than to take initiative, they prefer to uphold the status quo

7. Women tend to focus on accomplishing tasks rather than trying to reach an objective, they prefer to maintain a detailed daily work routine

The 'wiraswasta' or entrepreneur in Indonesian language was derived from the words 'wira' meaning primary, brave or warrior while the word 'swa' means alone and 'ta' being stand on one's own feet or to be independent. Thus the word 'wiraswasta' itself means a brave warrior that stood his/herself and become independent, a 'wiraswasta' or entrepreneur is expected to be able to take risks, creative and independent (Jurnal Pengkajian Koperasi dan UKM No.1 tahun I, 2006).

\section{Research Methodology}

The research is based on survey through questionnaire analysis to reach a conclusion based on respondents' answer on the questionnaire. The object of this research is South Sulawesi's Usaha Kecil Menengah segment with the samples being women employees of the home industries section.

The data is collected through means such as questionnaires, a structured list of questions on information technology, women roles and things that are needed to develop their skills that are distributed to the respondents in order to collect answers regarding said matters. Another mean to 
collect information is the interviews that are done to achieve a detailed description on the research object as well as to the data analysis. The interview was made with the owners of South Sulawesi's home industries.

Primary data are extracted directly from the questionnaires that were distributed to all of South Sulawesi's home industries, secondary data are extracted from literature research as well as journals from the internet

The population of this research is all of South Sulawesi's particularly Kota Makassar and Kabupaten Barru's home industries. Purposive sampling is the technique that was used in determining required sample for research. Sample retrieval is based on the criteria of having at least 1 (one) year experience of work and had shown significant asset development when compared to the original asset value. The questionnaire distribution on this research is done via accidental sampling in which both the researcher and respondent meet each other directly.

\section{Results and Discussion}

General description of respondent's education level. The number of respondents based on education levels are comprised as follows:

Table 1. General description of respondents based on education levels

\begin{tabular}{ccccc}
\hline & & Frequency & Percent & $\begin{array}{c}\text { Cumulative } \\
\text { Percent }\end{array}$ \\
\hline Valid & Elementary & 2 & 1.96 & 1.94 \\
& Junior High & 13 & 12.75 & 14.71 \\
School & & & \\
& High School & 62 & 60.78 & 75.49 \\
& D3 & 9 & 8.82 & 84.31 \\
S1 & 16 & 15.69 & 100 \\
\hline Total & 102 & 100 & \\
\hline
\end{tabular}

According to Table 1, 2 of the women entrepreneurs or $1.96 \%$ of them only finished elementary school, 13 people or $12.75 \%$ of them only finished junior high school, 62 people or $60.78 \%$ of them only finished high school, 9 people or $8.82 \%$ of them finished D3 Diploma degree, and 16 people or $15.69 \%$ of them managed to obtain S1 degree.

The information from the table indicates that most of the women entrepreneurs started their business on limited knowledge and education, thus forcing the need of knowledge improvement through seminars or workshops.

The government had allocated approximately Rp 5 billion in the form of credit supply for SME's via SME's throughout the year 1994-2006 to support the potential improvement of SME's. The government also approved the 2006 Rencana Kerja Pemda that had Support System Development (Pengembangan Sistem Pendukug) for SME's as one of their main programs. Based on the SME's population stated before, the UKM that had been led or owned by a woman comprised $45 \%$ of population or 500 entities. According to sample retrieval based on Slovin's formula, there are 222 total respondents.

The questionnaires allow more than one answers given for each question, this led to uneven number of analysis results.

Social Media Usage. Research result on information technology usage by South Sulawesi's SME's are as follows: 
Table 2. Social Media Usage

\begin{tabular}{lllll}
\hline & & Frequency & Percent & $\begin{array}{l}\text { Cumulative } \\
\text { Percent }\end{array}$ \\
\hline Va & Internet & 20 & 15.63 & 15.63 \\
lid & & 39.84 & 55.47 \\
& $\begin{array}{l}\text { Computer } \\
\text { (Word, }\end{array}$ & 51 & & \\
& Excel, etc) & & & \\
& $\begin{array}{l}\text { Software } \\
\text { Others }\end{array}$ & 14 & 10.94 & 66.41 \\
& Not using & 30 & 10.16 & 76.56 \\
& $\begin{array}{l}\text { any } \\
\text { information } \\
\text { technology }\end{array}$ & 23.44 & 100 \\
\hline Total & 128 & & \\
\hline
\end{tabular}

According to Table 2, 51 people or $39.84 \%$ of them have been using computer, but limited to Word Processing and Excel, 20 people or $15.63 \%$ of them have been using internet in their business, 14 people or $10.94 \%$ have used business specific software in their business but there are 30 people or $23.44 \%$ of them who had not used any information technologies whatsoever, this shows that the SME's at South Sulawesi have not fully maximized their utilization of Computer technology.

Social Media benefits. Social media benefits the business developments the most, in terms of both quality and quantity improvement due to the efficiency created when utilizing technology. Research on social media utilization had been done on some of South Sulawesi's SME's as shown on the next table.

Table 3. Social Media Utilization

\begin{tabular}{lllll}
\hline & Freq & Percent & Cumulative Percent \\
\hline Valid & Administration & 43 & 32.58 & 32.58 \\
Data Processing & 21 & 15.91 & 48.48 \\
Marketing & 28 & 21.21 & 69.70 \\
Others & 13 & 9.85 & 79.55 \\
Not utilized Social Media & 27 & 20.45 & 100 \\
\hline Total & 132 & 100 & \\
\hline
\end{tabular}

According to table 3, 43 people or $32.58 \%$ of them utilized information technology for administrative needs, 21 people or $15.91 \%$ of them utilized social media for data processing, 28 people or $21.21 \%$ of them used social media for marketing, 13 people or $9.85 \%$ of them used social media for other reasons and 27 people or $20.45 \%$ of them had not utilized social media at all.

Women's Role in SME's Development. Research results on women's role on SME's development is shown on the next table. 
Table 4. Women's role on SME's development

\begin{tabular}{lllll}
\hline & Frequency & Percent & $\begin{array}{l}\text { Cumulative } \\
\text { Percent }\end{array}$ \\
\hline Valid & $\begin{array}{l}\text { Reduce } \\
\text { financial weight } \\
\begin{array}{l}\text { Reduce } \\
\text { unemployment }\end{array}\end{array}$ & 55 & 39.29 & 39.29 \\
$\begin{array}{l}\text { Improve } \\
\text { financial }\end{array}$ & 21 & 40.00 & 79.29 \\
$\begin{array}{l}\text { condition } \\
\text { Others }\end{array}$ & 8 & 15.00 & 94.29 \\
\hline Total & 140 & 100 & \\
\hline
\end{tabular}

According to table 4, 55 people or $39.29 \%$ of them stated that they wanted to reduce their family's financial weight, 56 people or $40 \%$ of them stated that they wanted to reduce unemployment number, 21 people or $15 \%$ of them simply wanted to improve their family's financial condition and 8 of them had other reasons.

Table 5. Knowledge and Skills improvement needs

\begin{tabular}{|c|c|c|c|c|}
\hline & & Frequency & Percent & $\begin{array}{l}\text { Cumulative } \\
\text { Percent }\end{array}$ \\
\hline \multirow[t]{5}{*}{ Valid } & $\begin{array}{ll}\text { Business and } \\
\text { Marketing }\end{array}$ & 89 & 67.42 & 67.42 \\
\hline & $\begin{array}{l}\text { Consumer } \\
\text { Behavior }\end{array}$ & 13 & 9.85 & 77.27 \\
\hline & $\begin{array}{l}\text { Financial } \\
\text { Report }\end{array}$ & 26 & 19.70 & 96.97 \\
\hline & Others & 4 & 3.03 & 100 \\
\hline & Total & 132 & 100.00 & \\
\hline
\end{tabular}

In terms of knowledge and skills improvement, most of the women prefer business and marketing which comprised $67.42 \%$ of them or 89 people, 26 people or $19.70 \%$ of them prefer financial report, consumer behavior comprised $9.85 \%$ or 13 people of them and 4 people or $3.03 \%$ of them prefer other kinds of improvement. The data shows that most of the women entrepreneur wants to learn on how to market their product and how to manage their business.

Social Medias that are used in SME's development, mainly the one with women as managers have not been allocated its adequate place. This means that information technology uses are limited to administrative needs, in which it is used to simply help daily administrative work. This shows how the women UKM employees or managers needs further improvement in their knowledge on information technologies as they can become a valuable asset if utilized fully. Furthermore, women's skills and capabilities in utilizing the information technologies also requires improvement that can be done through training and simple workshops. It is also noted that it's best to do the training and workshop close to where they live to improve access.

The research also finds that women possess a good work ethics, this is shown from their high interest in contributing towards their family welfare while some of them are more interested in reducing unemployment number. These two findings show the determination possessed by the women thus forcing the need to give them the right direction and knowledge on how to manage their business. With said support, the women are expected to become a highly determined entrepreneur. 
The statement above supported the women's interest in knowledge and skills improvement on marketing and business management. As such, an appropriate mean to transfer information based on the women's preference is needed.

From the discussion above, there are a number of suggestions that are recommended in order to improve the quality of women entrepreneurs in SME's, such suggestions are as follows:

1. Constant training with the materials being:

a. Modern business management

b. Modern product marketing

c. Information technology in business

d. Practical information technology utilization

2. The materials themselves must be designed in a constant curriculum with predetermined indicators for achievements

3. Further supports are required after giving the materials needed, such as evaluation on field implementation

\section{Conclusion}

From the research findings and discussion, it can be determined several points regarding women entrepreneurs on South Sulawesi's SME's, such as:

1. Social Media have not been utilized fully to the maximum

2. Minimum level of social media skills

3. Questionnaire analysis shows high interest on marketing and business management in which these actions can be supported to further improve woman led SME's

From the conclusions above, the women entrepreneurs will require a constant training in form of material preparations, training, support and evaluation

\section{References}

Anonim, (2000). Wanita dan Pria Di Indonesia 2000, Biro Statistik Kesejahteraan Rakyat, BPS, Jakarta.

Anonim, (1994). Usaha Bersaing Untuk Wanita dan Pemuda, Ide Usaha Kecil dan Madya, Cakrawala Cinta, Jakarta.

B.S. Kusmuljono, (2007), Peran Keuangan Mikro dalam Mendukung Produktivitas Ekonomi Wanita, makalah disampaikan pada Rakor Pelaksanaan Kebijakan Peningkatan Produktivitas Ekonomi Wanita di Jakarta tanggal 28 Maret 2007

Gunari Budhiretnowati dan Rapma Siahaan (2006), Menggerakkan Denyut Nadi Koperasi Wanita dalam Menghadapi Era Globalisasi.

Jurnal Pengkajian Koperasi dan UKM (2006), Studi Peran Serta Wanita Dalam Pengembangan Usaha Kecil Menengah dan Koperasi, Nomor 1 tahun I

Roosganda Elizabeth (2007), Pemberdayaan Wanita Mendukung Strategi Gender Mainstreaming dalam Kebijakan Pembangunan Pertanian di Pedesaan, Pusat Analisis Sosial Ekonomi dan Kebijakan Pertanian, Bogor

Sri Lestari Harsosumarto ( 2007 ), Koperasi dan Pemberdayaan Perempuan, Kasubid Evaluasi dan Pelaporan serta Peneliti Muda Bidang Perkoperasian, Deputi Bidang Pengkajian Sumberdaya UKMK 